\title{
SECOND LIEUTENANT JAN BOŁBOTT FIGHTING IN "TYNNE" SECTION
}

\begin{abstract}
In the presented article, for the first time for many years, there have been made a partial analysis of events in "Tynne" section after the Soviet invasion on Poland on the $17^{\text {th }}$ of September 1939. Based on many sources, the author undertook a verification of the adjudications referring to the question, where the district "Tynne Wieś" commander, $2^{\text {nd }}$ Lieut. Jan Bołbott was during the fights, where, when and how he died. The author based on: the report of "Tynne" sector commander, Capt. Edmund Emil Markiewicz, reports of other soldiers of fortress battalion KOP "Sarny", who survived the war and other people, as well as archival sources that he got to and field research. According to the new adjudications, $2^{\text {nd }}$ Lieut. Jan Bołbott during the fights was in pillbox No. 4 "Pies", located just by the Słucz River, near to the ferroconcrete bridge ("the small bridge"), which had not been damaged before the Red Army's attack. It is accepted, that in the casemate the commander of "Tynne Wieś" had fallen with its crew during the Soviet sappers' assault on the casemate. However, it cannot be excluded, that he survived the storm and was executed at the area of Sochaki forest, Berducha farm or somewhere else. It was determined, that the assault occurred on the $19^{\text {th }}$ of September 1939, probably at the forenoon.

The conclusions and hypothesis from the article ought to be verified. The first research has already been conducted by Stowarzyszenie "Wizna 1939" and these adjudications are partly confirmed.
\end{abstract}

Keywords: Bołbott, Bołbot, Tynne.

\section{INTRODUCTION}

At the area of countryside Tynne (next to Sarny), by the Słucz River ${ }^{2}$, in Septemper 1939, there was a strongly fortified defense sector. It was a part of line of circumvallation, known as The Sosnkowski Line ${ }^{3}$."Tynne" sector ${ }^{4}$ was defended by the 4th company of $\mathrm{KOP}^{5}$ fortress battallion "Sarny". The sector (section) was divided into districts

\footnotetext{
${ }^{1}$ Dariusz Szymanowski, M.Sc., Faculty of History and Social Sciences, Cardinal Stefan Wyszyński University in Warsaw, ul. Wóycickiego 1/3, building 23, 01-938 Warszawa, e-mail: darek.szymanowski@wp.eu

${ }^{2}$ Nowadays Ukraine.

${ }^{3}$ Term used by the officers of the KOP battalion „Sarny”.

4 According to division system, "Sarny" section was divided into subsections: „Horyń", „Jarynówka” i „Czudel”. Subsection „Czudel” was divided into sectors: „Jeziory”, „Somino”, „Straszów”, „Czudel” and sector „Tynne”. Sector „Tynne” was divided into 4 districts: „Kamienne”, „Łącznikowy”, „Wieś” („Wieś Tynne”, or „Tynne Wieś”) and „Berducha”, where districts were the smallest areas in the structure of section division. In present publications and in the report of commander of sector, Emil Edmund Markiewicz, there are also names section or subsection „Tynne”, which mean „Tynne Wies” district.

5 Korpus Ochrony Pogranicza - the Border Protection Corps, a Polish military formation, established under the demand of the Minister of Military Gen. Władysław Sikorski from the $12^{\text {th }}$ of
} 
(subsections): "Berducha", "Tynne", "Łącznikowy" and "Kamienne", which were defended by heavy machine gun ${ }^{6}$ platoons: first, second, third and fourth respectively ${ }^{7}$. The members were mostly reservists from Lublin and Kraśnik, who were called up on the $28^{\text {th }}$ of August 1939. According to the company commander's ${ }^{8}$ report - there were 11 officers (reservists) and full number of riflemen ${ }^{9}$. One of the officers, a teacher from Lublin, $2^{\text {nd }}$ Lieut. $^{10}$ Jan Bołbott ${ }^{11}$, was the commander of subsection "Tynne".

As Capt. ${ }^{12}$ Markiewicz states in his report, during the fight from $18^{\text {th }}-21^{\text {st }}$ Sep 1939 the 691-member crew lost: 3 officers, 226 non-commissioned officers and riflemen, 36 people were hardly wounded and 301 of them were found missing (including 7 officers). Unfortunately, despite such a huge loss of human life, none of the Polish soldiers' graves have yet been found, including the one of $2^{\text {nd }}$ Lieut. Jan Bołbott.

Most of researchers exploring this topic thought until now, that during the combat $2^{\text {nd }}$ Lieut. Bołbott was in pillbox No. 9 (cryptonym "Pirat") and fell there with its crew ${ }^{13}$. There is also some different information about Bołbott's date of death - mainly two dates: $19^{\text {th }}$ of September ${ }^{14}$ or $20^{\text {th }}$ of September $1939^{15}$. It is also supposed that the pillbox crew fell during Soviet sappers' assault on pillbox "Pirat". This version was introduced in the report of the commander of section "Tynne"16.

The analysis of available source materials, actual reports of inhabitants of Tynne ${ }^{17}$, as well as field research, carried out by the author in 2012-2015, lead to other conclusions. They also suggest other version of events. Consequently, basing on these sources and field

September 1924 to protect the eastern borders of the Second Polish Republic. During the war the KOP units supplied the Polish Army.

${ }^{6}$ Further called: hmg.

${ }^{7}$ Polish Institute and Sikorski Museum (further called: PISM), Report of Emil Edmund Markiewicz, sign.B.I. $96 / \mathrm{h}$, p. 1.

${ }^{8}$ Captain Emil Edmund Markiewicz, born in 1907, Infantry Cadet School in Komorowo graduate, after graduating he moved to $27^{\text {th }}$ Infantry Regiment in Częstochowa. In 1939, after moving to fortress battalion „Sarny” he became the commander of $4^{\text {th }}$ company. After fights in sector „Tynne” at the days $18-20^{\text {th }}$ of September 1939, he joined to KOP Group of gen. W. Orlik-Ruckermann. After battle of Wytyczno he started conspiracy stint. He participated in Warsaw Uprising, where he served in a combat communication; he was promoted to major degree.

${ }^{9}$ PISM, Report of E.E. Markiewicz, sign. B.I. 96/h, p. 1.

${ }^{10}$ Second Lieutenant.

$112^{\text {nd }}$ Lieut. res. Jan Bołbott, born in 1911, in 1935-1939 studied on Faculty of Law and SocioEconomic Sciences of Catholic University of Lublin. In August 1939 was inducted to the $4^{\text {th }}$ fortress company of battalion "Sarny" as the platoon commander. The Minister of National Defence promoted him posthumously to degree of Polish Army lieutenant, under Decision from 12th of February 2014, No. 289/Kadr.

${ }^{12}$ Captain.

${ }^{13}$ T. Rodziewicz, Ppor. Jan Botbott (1911-1939), Lublin 2008, p. 9, and others.

14 C.K. Grzelak, Kresy w Czerwieni. Agresja Zwiazku Sowieckiego na Polskę w 1939 roku, Warszawa $1998, \quad$ p. 294 and others.

${ }^{15}$ T. Rodziewicz, Ppor. Jan Bolbott (1911-1939), Lublin 2008, p. 11, and others.

${ }^{16}$ PISM, Report of E.E. Markiewicz, sign. B.I. 96/h, p. 21.

17 The author's collections, Reports of Adam Sawczuk Łukaszuk and Andriej Omelkowiec Daniłowicz. 
researches ${ }^{18}$, I state that the pillbox commanded by $2^{\text {nd }}$ Lieut. Jan Bołbott during the fights in September 1939 was pillbox No. 4, cryptonym "Pies". It may be proved that the Red Army sapper's assault on the commander's casemate occurred on the $19^{\text {th }}$ of September in the forenoon. However, the $2^{\text {nd }}$ Lieut. Bołbott's death circumstances are not certain; we cannot exclude the possibility that he survived the storm and then, enslaved, he was killed with other Polish slaves.

\section{POLISH DEFENSE ORGANIZATION IN "TYNNE" SECTOR, SECTION "SARNY" - NEW ADJUTICATIONS}

The essential issue to reconstruct the sequence of events in sector „Tynne” at the days of $18-20^{\text {th }}$ of September 1939 is identifying, where on the Słucz "the small bridge" was located - the one, which Capt. Markiewicz mentioned more than 20 times in his report. It is also important for verifying, in which pillbox $2^{\text {nd }}$ Lieut. Jan Bołbott was during the fights.

An accurate analysis of source materials, including military maps and plans ${ }^{19}$, leaves no doubt that the bridge was located near to the casemate No. 4 "Pies", between the canal and this casemate. The bridge connected pathways leading along west and east bank of the Słucz River. It also provided path connection between countrysides Tynne and Berducha. Nowadays the Słucz River flows in a new riverbed. In the previous riverbed, which stays fully exposed and on riverbanks there is no remain of the bridge construction (on the ground). The reasons of this situation are unknown. Perhaps the construction elements were grabbed or they drifted with the stream of the river.

Nevertheless, we can deduce existing and localization of the bridge basing on other sources, inter alia archival documents - above-mentioned maps from the Central Military Archives, which show it accurately.

We should also focus our attention on the sketch made by Capt. Markiewicz after the war. Markiewicz marked on it the path from Tynne leading to Czabel through Berducha Farm. Even considering the fact, that it is only a sketch, which is very undetailed and imprecise, we can get some information from it about the pathway. According to this draft, the path leading eastwards from Tynne ("through the river"), evidently changes its direction to south, and then again to east, next to Berducha Farm, onto Czabel. Therefore it is a similar pathway as in the archival documents ${ }^{20}$.

\footnotetext{
${ }^{18}$ The electromagnetic device used to researches were: Lorenz Deepmax metal detector and Ramac $\mathrm{X} 3 \mathrm{M}$ ground-penetrating radar.

${ }^{19}$ Centralne Archiwum Wojskowe w Warszawie (further called: CAW), Gtówny Inspektorat Sit Zbrojnych, Plan rozbudowy fortyfikacji stałej, Pododcinek „Czudel”, Sektor „Tynne” rozplanowanie obiektów, sygn. I.302.4.2098; map Grupa „Tynne”, podz. ok. 1:5000, sygn. I.302.4.2103.

${ }^{20}$ Compare the pathway from Tynne to Berducha on fig. 1 and 2.
} 
Fig. 1 Sketch of „Tynne” sector (fragment), made by Capt. Markiewicz



Source: PIMS, Report of E.E. Markiewicz, sygn. B.I. 96/h, attachment

The information about the bridge and its construction is also mentioned in the report of Capt. Markiewicz. The surface and the whole bridge were made of strong and durable reinforced concrete. The construction was so strong, that blasting it with a ,2 $\mathrm{kg}$ payload which may destruct one span" ${ }^{21}$ caused only a small surface damage at the explosion point. From this fact we can conclude that the bridge had more than one span. It must be noted that the spans were located "under water" 22 , therefore it was a low water bridge. This is very relevant information, because it negates a hypothesis, that the bridge could have been the wooden one, between weir "Przekora"23 and casemate No. 4 "Pies" (the one, which economic rail tracks led through to the pillboxes of subsection "Berducha" beyond the river). Because, as it is reported by habitants ${ }^{24}$, it was a wooden and high bridge (up to $3 \mathrm{~m}$ above water), which got damaged before the war. It also could not have been located on weir "Przekora", which the narrow-gauge railway led through, because the tracks were built on the pillars of the weir, high above water (about $3 \mathrm{~m})^{25}$.

\footnotetext{
${ }^{21}$ PISM, Report of E.E. Markiewicz, sygn. B.I. 96/h, p. 9.

${ }^{22}$ Ibidem, p. 11.

${ }^{23}$ Weir „Przekora” was built on the Słucz River on the south edge of „Tynne” sector, next to pillbox No. 5 of "Berducha" district (at the place called Łysa Góra). The purpose was to enable flooding the defense areas, in case of Soviet invasion of Poland. Building of this weir had not been finished before the war's outbreak and the weir did not fulfil its idea.

${ }^{24}$ The author's collections, Report of Adam Sawczuk Łukaszuk, inhabitant of Berducha village, born in 1929.

${ }^{25} C f$. photo 1 .
} 
Photo 1. The remains of weir „Przekora” on the Słucz River

Source: own materials

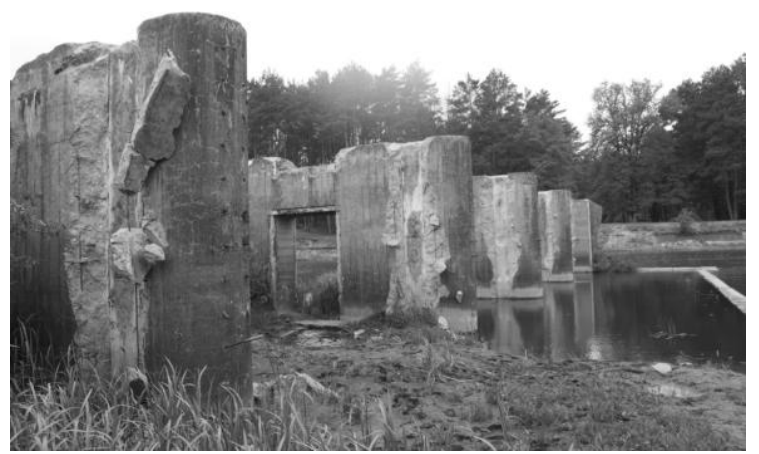

Moreover, geophysical surveys of the ground, carried by the author at the area of pillbox No. 4 "Pies" 26 , confirmed that by both sides of previous riverbed, at the place of probable bridge localization, there are remains of former path. The path had a width of about $3-5 \mathrm{~m}^{27}$, led from Tynne to Berducha and it was signed in above-mentioned archival documents. The device also registered a change in the ground's structure, on the west bank of the former riverbed, at the depth of about $0,5 \mathrm{~m}$ and on the line of about $6 \mathrm{~m}$ width. It might have been caused by the bridgehead, possibly located earlier in this place. Eventually, the survey results can indirectly confirm, that in this place in the past there was a river crossing (the riverbed had there a width of $20-25 \mathrm{~m}^{28}$ ).

Photo 2. The view for the path leading across the former bed of the Stucz River (and „the small bridge"), near to pillbox No. 4 "Pies", identified on a base of geophysical research of the ground conducted in this place.

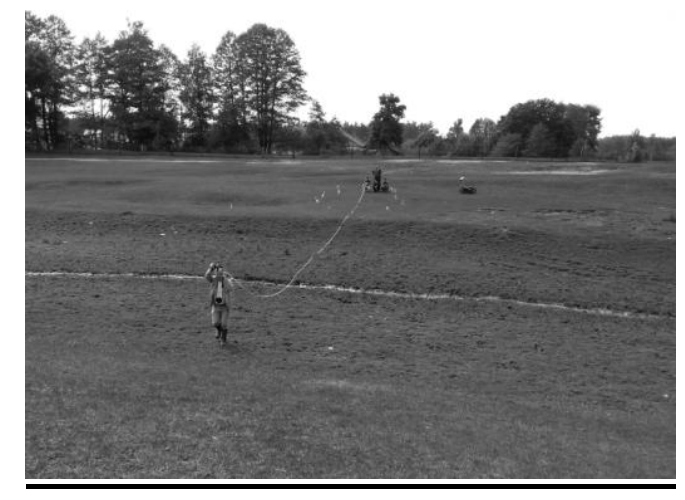

Source: S. Nowakowski

\footnotetext{
${ }^{26}$ Ground-penetrating survey of ground profiles was conducted on the 23th of May 2015, files DAT_272-302, in the author's collections.

${ }^{27} \mathrm{Cf}$. photo 2 .

${ }^{28}$ The width of former riverbed had been directly measured on the 23th of May 2015.
} 
Until now it was thought, that "Tynne" subsection commander, $2^{\text {nd }}$ Lieut. Jan Bołbott's casemate was "Pirat" No. 9, located in Tynne countryside, $800 \mathrm{~m}$ westward the Słucz River ${ }^{29}$. But today there are strong arguments to verify it.

It seems that the mistake was due to assuming the project of "Tynne" sector fortification as the final one, basing on the plan from the documents archive in General Command of Polish Armed Forces ${ }^{30}$. On this document pillbox No. 9 "Pirat" in "Tynne Wieś" was signed as the district commander's pillbox. It is important that this document was prepared just as a project, when the fortifying works were still undone. It does not show real organization of sector's defense line at the day of Soviet invasion on Poland.

After analyzing source documents and verifying them in the terrain, I think that "Tynne" commander's real pillbox (where he fought and perhaps died) is pillbox No. 4 "Pies", located near to the bridge on the Stucz River. The base of this thesis are notes from "Tynne" subsection commander's report, which was written after war" ${ }^{31}$.

Capt. Markiewicz in his report clearly suggests, that the commander's pillbox was located by the river: "There was a short fight of a tank and the object staying by the river (object of $2^{\text {nd }}$ Lieut. Bełbot ${ }^{32}$ ), 33 .

Basing on this sentence we can conclude, that pillbox No. 9 "Pirat", located far at the countryside about $800 \mathrm{~m}$ from the river, could not have been the commander's pillbox, because it did not stand by the Słucz ${ }^{34}$. At "Tynne" district, directly by the river, there were casemates No. 3 "Piorun" and No. 4 "Pies" - "Piorun" was placed next to the Orthodox church and "Pies" about $1 \mathrm{~km}$ southward".

The report also suggests, that at „Tynne” subsection only two pillboxes did not have installed cupolas and they were located just by the river:

"After getting to Tynne I saw, that most of platoons stayed at the countryside - as uncommitted force of the subsection commander. Only two objects - located just by the river, by both sides of the stone bridge - were prepared. [...] They had not been fully done yet. Actually, on the whole company section the situation was similar - because if an object construction was finished, it did not have some interior equipment, or - as it was in Tynne subsection - there were two objects without »cloches«, i.e. steel cupolas protruding from the ferroconcrete." 36 .

\footnotetext{
${ }^{29}$ Z. Pruski, Bastion Polesie. Polskie fortyfikacje na Polesiu 1920-1939, Przasnysz 2000, p. 117; T. Rodziewicz, Agresja Sowiecka 17 września 1939 roku na Kresach Wschodnich i Lubelszczyźnie. Studia i materiaty, t.1, Lublin 2011, p. 88.; idem, Ppor. Jan Botbott (1911-1939), Lublin 2008, p. 9; http://pl.wikipedia.org/wiki/Tynne [date of access: 30 marca 2015 r.].

30 CAW, GISZ, Plan rozbudowy fortyfikacji statej, Pododcinek „Czudel”, Sektor „Tynne”rozplanowanie obiektów, sign. I.302.4.2098.

${ }^{31}$ E.E. Markiewicz wrote his report in 1951.

32 Capt. Markiewicz uses incorrect surname of „Tynne” district commander - in his report it is Bełbot, instead of Bołbott.

${ }^{33}$ PISM, Report of E.E. Markiewicz, B.I. 96/h, p. 18.

${ }^{34}$ Cf. fig. 2.

${ }^{35}$ As above.

${ }^{36}$ PISM, Report of E.E. Markiewicz, B.I. 96/h, p. 6.
} 
Fig. 2. Sketch of the disposition of pillboxes at „Tynne" and „Berducha” districts, made on a base of "Plan rozbudowy fortyfikacji stałej. Pododcinek »Czudel«, Sektor »Tynne«"

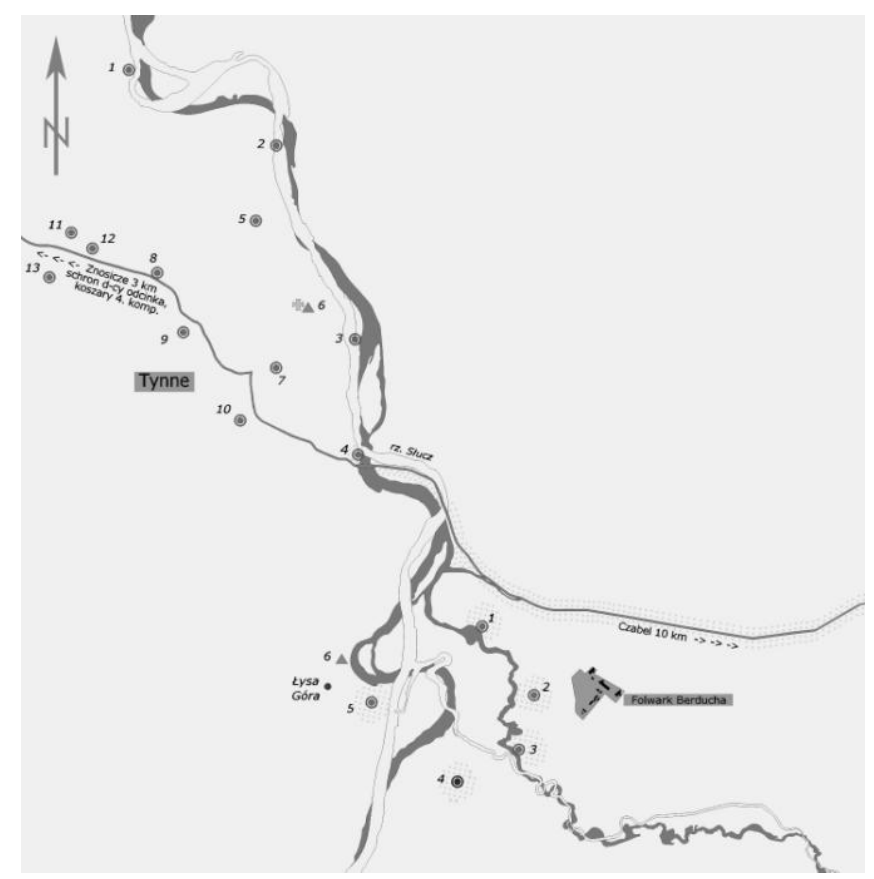

Source: own elaboration

Undoubtedly, one of these non-cupolated pillboxes was $2^{\text {nd }}$ Lieut. Bołbott's pillbox. During the conversation with Capt. Markiewicz he informed: "At night I blocked the hole at the roof with some material - ammunition boxes, beds, mattresses and others" ${ }^{\text {, }}$, which proves, that his pillbox did not have a cupola. Therefore I think, that $2^{\text {nd }}$ Lieut. Bołbott's casemate, as one of two mentioned above, was located ,just by the river".

The second object located just by the river was pillbox No. 3 "Piorun", which - as we can conclude from the report - also did not have a cupola.

Pillboxes 3 and 4 were combat pillboxes, built for 16-people crew - 3 noncommissioned officers and 13 privates. They should have been armed with 2 hmgs and 1 $\mathrm{lmg}^{38}$ in loopholes and $1 \mathrm{hmg}$ in a cupola ${ }^{39}$. The conclusion is that these casemates' combat capability was strongly limited due to lack of cupolas.

Because both objects were located just by the river, I think that $2^{\text {nd }}$ Lieut. Jan Bołbott fought in one of them. Other extracts of Capt. Markiewicz's report suggest which pillbox

\footnotetext{
${ }^{37}$ Ibidem, p. 19.

${ }^{38}$ Light machine gun.

39 CAW, GISZ, Warunki wykonawcze. Pododcinek „Czudel-Bereźne”. Sektor „Tynne”, sign. I.302.4.2099, pp. 22-25, 30-33.
} 
it was, for example: "on his ${ }^{40}$ nearest foreground there was a reinforced-concrete bridge, connecting BERDUCHA with TYNNE",41.

On a basis of the carried research I state, that the bridge was placed about $100 \mathrm{~m}$ from pillbox No. 4 "Pies" and about $1 \mathrm{~km}$ from pillbox No. 3 "Piorun". The crossing was on the nearest foreground of casemate "Pies", therefore I state, that this was the subsection commander's pillbox.

The next argument which proves that during the fights with the Red Army Bołbott was on other position than it was thought before, is his conversation with the commander. Capt. Markiewicz mentions it: "At 2am - 19.9.39, subsection »Tynne« commander [...] noticed one enemy tank on the bridge" ${ }^{42} \cdot 2^{\text {nd }}$ Lieut. Bołbott could not have seen this tank, because (according to the report) it was night. In addition, there was thick fog on the field, which disappeared only in the morning ${ }^{43}$. The possibility, that the tank could have used a headlight, does not matter. That is because the headlight disappeared in the fog few meters further. Therefore the tank on the bridge had to be so close to $2^{\text {nd }}$ Lieut. Bołbott, that he probably was able to hear it without any visibility. It is possible that he heard the throb of engine and the sound of rotating wheels and tracks. As mentioned above, the pillbox located nearest to the bridge was "Pies" No 4. According to this, in my opinion, localizing the tank on the bridge was possible only while staying in this pillbox and in such conditions.

The next relevant information which can indirectly confirm, that the subsection commander was in pillbox No. 4 "Pies", may be concluded from this quotation: "2 ${ }^{\text {nd }}$ Lieut. Bełbot reports half an hour later, that he's already in front of the enemy. Some enemy patrol $[\ldots]$ attacked his right-flank object, but from the south - from direction of »Tyszyca« company"44. This statement proves, that $2^{\text {nd }}$ Lieut. Bołbott had on his right only one object bordering with "Tyszyca" company. The pillbox directly bordering with the company was "Wyciage" No. 5 (at "Berducha" district), which is a right-flank object for pillbox No. 4 "Pies" ${ }^{45}$. It corresponds with above-mentioned conclusions.

According to Capt. Markiewicz's report, the subsection commander's object was "located northward the pathway" and with its right-flank object they were "two first objects" $"$. By this collocation we should understand two combat pillboxes, placed southernmost from the sector commander's position.

Assuming that $2^{\text {nd }}$ Lieut. Bołbott's casemate and its right-flank casemate were two first objects of the "Tynne" section and that the commander's pillbox stood northward the path, I conclude that the commander's pillbox was "Pies" No. 4. In fact, this object was located about $100 \mathrm{~m}$ northward the pathway Tynne-Berducha, which led through "the

\footnotetext{
40 „Tynne” subsection commander's.

${ }^{41}$ PISM, Report of E.E. Markiewicz, , B.I. 96/h, p. 5.

${ }^{42}$ Ibidem, p. 18.

${ }^{43}$ Ibidem, p. 13. Capt. Markiewicz mentions, that at night on the $18^{\text {th }}$ of September 1939 the fog was so thick, that in some places the visibility was restricted even to less than $10 \mathrm{~m}$. In this season the phenomenon was constant. It usually lasted until morning and disappeared only when the sun "started to operate well".

${ }^{44}$ Ibidem, p. 14.

${ }^{45} \mathrm{Cf}$. fig. 1 and 2.

${ }^{46}$ PISM, Report of E.E. Markiewicz, B.I. 96/h, p. 15.
} 
bridge". Furthermore, with casemate No. 5 "Wyciąg", it was the southernmost pillbox from "Tynne" section".

It is also worth noting, that mentioned above pillbox No. 5 "Wyciąg" was intended as subsection "Berducha" commander's place. Capt. Markiewicz's report informs, that it was "included" to subsection "Tynne" and subsection "Berducha" commander took a position in one of pillboxes by east riverside. It can additionally confirm, that the decision about placing the troops in casements was taken just before fighting and it was caused by the circumstances.

Casemate No. 4 "Pies" stood in a strategic place: next to the pathway from Berducha to Tynne, where the attack was supposed to start. It was also a perfect observation point onto district "Berducha" pillboxes, placed beyond the river, which allowed to control what happened in this section. Moreover, it should be noted, that casemate No. 4 did not have a cupola, which strongly limited its combat capabilities. In my opinion, these circumstances justified the decision to assign this one pillbox to $2^{\text {nd }}$ Lieut. Bołbott, who, in section commander's opinion, was the most admirable company officer and was really appreciated by him.

\section{3. $2^{\text {ND }}$ LIEUT. JAN BOŁBOTT - DATE OF DEATH AND ITS CIRCUMSTANCES}

We cannot exclude, that $2^{\text {nd }}$ Lieut. Jan Bołbott could have survived the assault on his pillbox and then, after having been slaved, he was killed with other slaves in "Berducha" district or somewhere else. I conclude that after analyzing available source materials, especially E.E. Markiewicz's report, and considering Soviet sappers' method of neutralizing pillboxes. During the assaults, the Red Army sappers blasted entrances to pillboxes, and after that they entered.

Such way of seizing the abutting pillbox (probably it was "Piorun" No. 3) was described by $2^{\text {nd }}$ Lieut. Jan Bołbott in his direct conversation with the commander ${ }^{48}$ " $2^{\text {nd }}$ Lieut. Bełbot reports, that a moment ago there occurred an explosion in the abutting object and he saw the enemy getting inside" $" 4$. The assault on $2^{\text {nd }}$ Lieut. Bołbott's casemate could have looked similar. It occurred after a moment, during this conversation: "I couldn't have finished my sentence as I heard a crack on the phone, and I deducted that there was already no connection. $2^{\text {nd }}$ Lieut. Bełbot's object and all the crew had been killed 2 officers and 49 people suffocated or even were burnt" ${ }^{30}$.

"The crack on the phone", remembered by the commander, was undoubtedly caused by losing connection during the assault. However, he did not see this situation, because at the moment of explosion he was $4 \mathrm{~km}$ further - in the commander's casemate in Znosicze. Therefore, we cannot exclude, that $2^{\text {nd }}$ Lieut. Bołbott survived the assault and shared the probable fate of other soldiers of sector "Tynne". Of course, it would not change his role and bravery in fighting. It would be only the beginning of further searching for the remains of this heroic officer. It is very relevant that this is only a hypothesis, which should not be excluded, but ought to be verified in each possible way.

\footnotetext{
${ }^{47}$ Cf. fig. 2.

${ }^{48}$ Capt. E.E. Markiewicz.

${ }^{49}$ PISM, Report of E.E. Markiewicz, B.I. 96/h, p. 15.

${ }^{50}$ Ibidem, p. 21.
} 
Important information about the date and time of assault on $2^{\text {nd }}$ Lieut. Bołbott's pillbox is concluded from the report of Adam Kotuła and Mieczysław Kalicki. Cpl. Mieczysław Kalicki stated, that there had been such a strong explosion of the nearby pillbox (150-200 $\mathrm{m}$ further ${ }^{51}$ ), that only rubble left in this place ${ }^{52}$ - it was "Piorun", pillbox No. 3 located just by the river ${ }^{53}$.

Probably it was the same explosion which $2^{\text {nd }}$ Lieut. Bołbott witnessed, when he was making a report to his commander at the end of the fight. That is because pillbox No. 4 was for it the abutting one ${ }^{54}$ : " $2^{\text {nd }}$ Lieut. Bełbot reports, that a moment ago there occurred an explosion in abutting object and he saw the enemy getting inside" $" 55$.

This is a very relevant conclusion, especially when we compare it to the report of telephonist Adam Kotuła: "Sometime later Markiewicz calls, he called all the time. Colonel, $2^{\text {nd }}$ Lieut. Bołbott should get an order! It was the $19^{\text {th }}$ in the morning, 9 or 10 o'clock, I don't remember. The company commander did not see what was happening, he only heard it on the phone. And he keeps talking $-2^{\text {nd }}$ Lieut. Bołbott, because he fights etc. That would mean that some of them ${ }^{56}$ had already given up. Kalicki ${ }^{57}$ said, that also about 11 o'clock they had blasted this fort, I don't know, one or two. He did not know if they'd blasted the one, where Bołbott stayed; he only knew, that they'd been blasted ${ }^{58}$ and these Soviets had come to them and started talking: give up or we'll blast you, like this pillbox. So this lieutenant ${ }^{59}$ gave up. It's only me who concludes, firstly - that the explosion happened ${ }^{60}$, secondly - that Markiewicz did not tell anything about Bołbott later"61

These reports let determine quite accurately, when the assault on $2^{\text {nd }}$ Lieut. Bołbott's casemate took place $^{62}$. But they do not let state unambiguously, whether the explosion was fatal to the crew, or it just broke the telephone connection.

The information about $2^{\text {nd }}$ Lieut. Jan Bołbott's date of death is also mentioned by Lt.-Col. ${ }^{63}$ Nikodem Sulik ${ }^{64}$. According to him, it was the $19^{\text {th }}$ of September 1939. It collides with Capt. Markiewicz's report, which suggests that it was the $20^{\text {th }}$

\footnotetext{
${ }^{51}$ During the fights Cpl. Kalicki was in pillbox No. 6 "Piekło", located near to the Orthodox church.

${ }^{52}$ C.K. Grzelak, Kresy w czerwieni 1939. Agresja Związu Sowieckiego na Polskę, Warszawa 2008 , p. 248.

${ }^{53}$ Cf. fig. 2.

${ }^{54}$ As above.

${ }^{55}$ PISM, Report of E.E. Markiewicz, B.I. 96/h, p. 21.

${ }^{56}$ The pillboxes.

${ }^{57}$ Cpl. Mieczysław Kalicki.

${ }^{58}$ The pillboxes.

${ }^{59} 2^{\text {nd }}$ Lieut. res. of Art. Stanisław Maciąg, the commander of pillbox No. 6 "Piekło", after blasting the abutting pillbox "Piorun" by Soviets, called by them to give up. He was taken to slavery with the pillbox crew and then, after crossing the river, shooted there.

${ }^{60}$ The pillbox.

${ }^{61}$ The author's collections, Report of Adam Kotuła from October 2012.

${ }^{62}$ On a base of archives query which I made, I state, that it was the 19th of September 1939, between 10 and 11 o'clock.

${ }^{63}$ Lieutenant Colonel.

${ }^{64}$ N. Sulik, Okruchy wspomnień, Białystok 1993, p. 53.
} 
of September ${ }^{65}$; in my opinion, considering available information about fighting in section "Sarny", this date is doubtful ${ }^{66}$. Lieut. Adam Kotuła also takes notice of this. During fights with Bolsheviks he was a telephonist in regiment commander's pillbox and he received reports from Capt. Markiewicz about the situation. He also confirmed, that the fights in Tynne lasted less, than it was related by section "Tynne" commander ${ }^{67}$. It would also suggest, that $2^{\text {nd }}$ Lieut. Bołbott fell on the $19^{\text {th }}$ of September 1939.

\section{STILL UNANSWERED QUESTIONS}

Of course, as in every research of this type, there are still many doubts and questions, which we have not answered yet. The doubts do not negate the conclusions we made. Clarifying them, though, can be very important for more detailed reconstruction of fighting history in Tynne area - or even in "Sarny" section. This is the reason, why we should consider them.

We still do not know, what happened with bodies of KOP soldiers, fallen or murdered in this section. And basically, we have not answered the question: where the remains of $2^{\text {nd }}$ Lieut. Jan Bołbott's are now?

From Capt. Markiewicz's memories we can know, that from about 700-people crew of $4^{\text {th }}$ company in sector "Tynne" more than 200 soldiers were killed and about 300 were found missing ${ }^{68}$. There is no doubt then, that the loss of human life had to be huge. However, nobody has found any of Polish soldiers' graves yet. Then what happened with the dead bodies? Did anyone bury them? Were they buried in their fighting area, or maybe they were transported somewhere and then graved there?

We can conclude that there might be a mass grave near to Tynne, basing on one of preserved (indirectly) messages. In the letter to TVP programme "Rewizja Nadzwyczajna", televiewer Julian Grzesik referred to the report of a witness, who lived near to Tynne at that time. He wrote: "On the $17^{\text {th }} / 18^{\text {th }}$ of September 1939 infantry troop of unidentified Polish Army unit [...], had a fight. It was enveloped and destroyed by Soviet armoured unit. Some soldiers, at the number of 280 , were taken to slavery in Nosicze $^{69}$ village, about $3 \mathrm{~km}$ from Tynne, county Sarny. The slaves in 50-people groups, with hands on their heads, were led by Soviet escorts. They went from Nosicze, through Tynne, to village Czabel, Suchacki forest ${ }^{70}, 12 \mathrm{~km}$ further. They stopped near to the farm Berducha and they were executed there. In a few days after this crime, the witness and his

\footnotetext{
${ }^{65}$ The report of E.E. Markiewicz suggests, that $2^{\text {nd }}$ Lieut. Jan Bołbott died on the 20th of September 1939.

${ }^{66}$ The duration of fights in Tynne and date of Jan Bołbott's death are also doubtful for historians, who explore the theme of eastern border fights, i.a. C.K. Grzelak, J. Prochwicz. More [w]: C.K. Grzelak, Kresy w czerwieni 1939. Agresja Związu Sowieckiego na Polskę, Warszawa 2008, p. 249, J.R. Prochwicz, Formacje Korpusu Ochrony Pogranicza w 1939 r., Warszawa 2003, p. 244, and others.

${ }^{67}$ The author's collections, Report of Adam Kotuła from October 2012.

${ }^{68}$ Inter alia $2^{\text {nd }}$ Lieut. Bołbott reported to his commander during the fight, that there were 28 killed people, and then he informed about the next 23 .

${ }^{69}$ Certainly he meant Znosicze village.

${ }^{70}$ Согаки forest is located northward the Słucz River. Local people pronounce Согаки as "Sochaki”, „Suchaki” - which probably was the reason, why name „Suchacki forest” is used in the report (from word Sochaki or Suchaki).
} 
mother were at the crime scene. They saw newly-made graves and Polish military uniforms protruding with them; perhaps they were taken by wild animals or people. Now at the scene of the crime there is a forest and the place is not signed"71. Although this message a bit inaccurate and has some wrong information, it should by precisely analyzed. Moreover, there are reports of people, who survived the war ${ }^{72}$. They state, that many Polish soldiers after fights in Tynne were taken to Soviet slavery. Then they were transported to Olewsk, the first Soviet town, where later there was a slave exchange with Germans. This fact was mentioned by Adam Kotuła, who received such information from Mieczysław Kalicki - a telephonist in pillbox No. 6 "Piekło", located next to the Orthodox Church, who was taken to Soviet slavery after fighting in Tynne ${ }^{73}$. According to Cpl. Kalicki, directly after being slaved, "the fort crew was led through remaining bridge on Stucz. After crossing it, the slaves were guided to the group of Soviet officers, who were standing next to the fort, beyond the river" ${ }^{\text {74 }}$. On the whole "Tynne" section, beyond the river, there were only 4 pillboxes of "Berducha" district ${ }^{75}$. Other pillboxes were located by the west side of the Stucz River. As the report suggests, the slaves went through the bridge next to these casemates. Therefore if we assume, that described pathway led from Znosicze through Tynne, the bridge on Słucz (nearby pillbox No. 4) and then towards Berducha and Czabla ${ }^{76}$, we can conclude, that the report of Julian Grzesik corresponds with Cpl. Kalicki's memories.

The letter also informs, that all the slaves were killed at the area of Berducha farm. This information is wrong, though, in confrontation with the report of Kalicki, who was one of these Polish slaves. Some soldiers and non-commissioned officers, including Cpl. Kalicki, were taken to Olewsk and the rest was killed. Certainly, the Soviets did not kill the whole 280-people group and perhaps this is the "missing" group, mentioned by Capt. Markiewicz.

A doubtful question, due to Markiewicz's report, is also the number of soldiers, who could have been in subsection commander's casemate during the explosion. According to Markiewicz, $2^{\text {nd }}$ Lieut. Bołbott was not the one who died - there were 1 officer and 49 soldiers except him $^{77}$.

The information above suggests, that inside the object there were 51 people. However, neither of pillboxes: "Pies" No. 4 and "Pirat" No. 9, suggested before as the district commander's one, was supposed for such number of people. Casemate No. 4 was a typical combat casemate, intended for 16 soldiers $^{78}$. Casemate No. 9 "Pirat", which should have been the commander's casemate according to the plan, was intended for 104

\footnotetext{
${ }^{71}$ Archiwum Straży Granicznej w Szczecinie, Korpus Ochrony Pogranicza. Zbiór spuścizn i relacji, sygn. 2237/12, p. 59.

${ }^{72}$ Inhabitants of Tynne and vicinity of that time.

${ }^{73}$ C.K. Grzelak, Wrzesień 1939 na Kresach. W relacjach, Warszawa 1999, pp. 269-270

${ }^{74}$ Ibidem

${ }^{75}$ Pillbox No. 1 „Wyrok”, No. 2 „Wyłaz”, No. 3 „Wyskok”, No. 4 „Wylew”.

${ }^{76} \mathrm{Cf}$. fig. 2.

${ }^{77}$ PISM, Report of E.E. Markiewicz, B.I. 96/h, p. 21.

${ }^{78}$ CAW Warunki wykonawcze. Pododcinek „Czudel-Bereźne”. Sektor 'Tynne”, sign. I.302.4.2099, pp. 30-33.
} 
people $^{79}$. Still unsettled question is whether Capt. Markiewicz was wrong, suggesting this pillbox as the commander's one, or maybe it was another aberration.

Due to many questions, which we still have not managed to answer, it will be necessary to carry other source queries and field research. One of such research was carried by Stowarzyszenie "Wizna 1939" in may $2015^{80}$ in Sochaki forest, by the east side of the Shucz, far from the fighting area. The expedition conducted by the author probably found the remains of above mentioned place, where Polish soldiers and officers were executed and buried. During the survey, at the area about $100 \mathrm{~m}^{2}$ there were found: buttons of Polish uniforms and soldiers' underclothing, Polish coins used before the war, a medallion and a dog tag of Adam Knieja, born in $1908^{81}$; there were also found cartridge cases from Mosin machine gun and pieces of a barbed wire, which could entwine Polish soldiers' arms ${ }^{82}$. The research will be continued.

Photo. 3, 4. The dog tag found at the area of Sochaki forest, next to Tynne
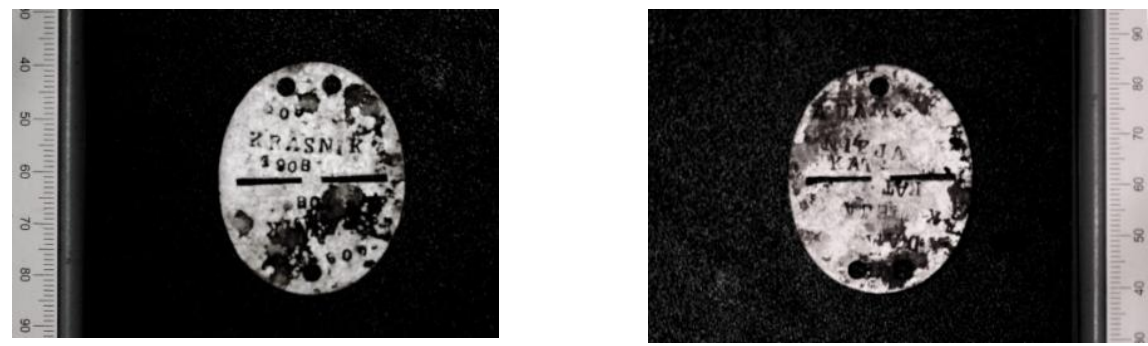

Source: own materials

\section{REFERENCES}

[1] Agresja sowiecka na Polskę w świetle dokumentów. 17 września 1939, Działania wojsk Frontu Ukraińskiego, T. 2, wybór i oprac. C. Grzelak, S. Jaczyński, E. Kozłowski, Warszawa 1996.

[2] Cygan W.K., Kresy w ogniu. Wojna polsko-sowiecka 1939, Warszawa 1990.

[3] Grzelak C.K., Kresy w czerwieni, Warszawa 1998.

[4] Grzelak C., Stańczyk H., Kampania polska 1939 roku, Warszawa 2005

[5] Markiewicz E.E., Relacja z przebiegu działań bojowych w 1939 lodtworzona na podstawie zapisków/, miejsce przechowywania Instytut Polski i Muzeum Sikorskiego w Londynie.

79 Ibidem, pp. 66-69.

${ }^{80} \mathrm{http}: / /$ www.wizna1939.eu/index.php/97-tynne-slady-zbrodni-sowieckiej-na-zolnierzach-kop [date of access: 23.06.2015 r.].

${ }^{81}$ Adam Knieja's niece confirmed, that her uncle had not returned from war and nobody knew, where he had fallen (the author's conversation with Marianna Jóźwiak - audio recording from the 23th of June 2015, in the author's collections).

${ }^{82}$ The findings were ceded to the representative of НАНУ - Національна Академія Наук Украӥни, who supervised the survey. During the expedition the crew did not search for the remains of killed soldiers, because it is necessary to get another permissions; the next research works are planned for October 2015. 
[6] Moczulski L., Wojna Polska 1939, Warszawa 2009.

[7] Porwit M., Komentarze do historii polskich działań obronnych 1939 roku, Warszawa 1983.

[8] Prochwicz J.R., Formacje Korpusu Ochrony Pogranicza w 1939 roku, Warszawa 2003.

[9] Pruski Z., Bastion Polesie. Polskie fortyfikacje na Polesiu w latach 1920-1939, Przasnysz 2000.

[10] Sulik N., Okruchy wspomnień, Białystok 1993.

[11]Wojna polsko-sowiecka 1939. Tło polityczne, prawno międzynarodowe i psychologiczne. Agresja sowiecka i polska obrona. Sowieckie zbrodnie wojenne $i$ przeciw ludzkości oraz zbrodnie ukrainskie i białoruskie, t. 2, Dokumenty, oprac. R. Szawłowski (ps. Karol Liszewski), Warszawa 1997.

\section{PODPORUCZNIK JAN BOLBOTT W WALKACH NA ODCINKU „TYNNE”}

W niniejszym artykule po raz pierwszy od wielu lat dokonano częściowej analizy wydarzeń na odcinku "Tynne" po inwazji Związku Sowieckiego na Polskę 17 września 1939 r. Bazując na wielu źródłach autor podjął się weryfikacji dotychczasowych ustaleń odnoszących się do kwestii, gdzie dowódca rejonu „Tynne Wieś”, ppor. Jan Bołbott, przebywał w trakcie walk, a także kiedy i w jakich okolicznościach poległ. Autor opierał się na relacji dowódcy odcinka „Tynne” kpt. Emila Edmunda Markiewicza, relacjach innych żołnierzy baonu fortecznego „Sarny”, którzy przeżyli wojnę oraz innych osób. Wykorzystał także inne źródła archiwalne, do których dotarł. Ponadto analiza została poparta wnioskami wynikającymi z badań terenowych. Zgodnie z nowymi ustaleniami ppor. Jan Bołbott przebywał w trakcie walk w schronie nr 4 o kryptonimie „Pies”, położonym tuż nad rzeką Słucz, w pobliżu żelbetowego „mostku”, którego polscy żołnierze nie zdołali zniszczyć przed atakiem Armii Czerwonej. Przyjmuje się, że dowódca rejonu „Tynne-Wieś” poległ wraz $\mathrm{z}$ załogą $\mathrm{w}$ czasie szturmu sowieckich saperów na schron. Nie można jednak wykluczyć, że szturm ten przeżył i został rozstrzelany w rejonie lasu Sochaki, folwarku Berducha lub w innym miejscu. Ustalono także, że atak na schron nastąpił 19 września w godzinach przedpołudniowych.

Wnioski i hipotezy zawarte w artykule powinny być zweryfikowane. Pierwsze takie badania zostały już przeprowadzone przez Stowarzyszenie „Wizna 1939”, a ich wyniki wstępnie potwierdziły zaprezentowane ustalenia.

Slowa kluczowe: Bołbott, Bołbot, Tynne.

DOI:10.7862/rz.2015.hss.28

Przesłano do redakcji: maj 2015

Przyjęto do druku: lipiec 2015 